\title{
13. MAGNETIC HYSTERESIS PROPERTIES OF FINE-GRAINED MAGNETIC IRON SULFIDE NODULES AND CRUSTS ON THE AMAZON FAN ${ }^{1}$
}

\author{
Frank R. Hall, ${ }^{2}$ Stanley Cisowski, ${ }^{3}$ and John W. King ${ }^{4}$
}

\begin{abstract}
The sediments from Ocean Drilling Program Leg 155 included authigenic magnetic-mineral phases. Four iron sulfide nodules, up to $5 \mathrm{~cm}^{3}$ in volume, and a single iron sulfide crust $\left(\sim 2 \mathrm{~cm}^{3}\right)$ were analyzed for magnetic hysteresis properties. The results indicate that these authigenic minerals are fine grained and behave as single-domain sized particles. Camera X-ray diffraction and chemical analyses using the scanning-electron microscope indicate that the authigenic minerals are composed of greigite $\left(\mathrm{Fe}_{3} \mathrm{~S}_{4}\right)$.
\end{abstract}

\section{INTRODUCTION}

Authigenesis and reduction diagenesis can play important roles in defining the magnetic mineralogy of sediments (e.g., Karlin and Levi, 1983). These processes result in (1) the formation of iron oxides (i.e., bacterial magnetite $\left[\mathrm{Fe}_{3} \mathrm{O}_{4}\right]$ and/or, (2) the formation of iron sulfides by precipitation from pore waters, and/or (3) the dissolution of detrital iron oxides with the subsequent development of iron sulfides. These processes require relatively high organic carbon contents and bacterial mediation. The bacteria reduce pore-water sulfate $\left(\mathrm{SO}_{4}{ }^{2+}\right)$ to sulfide $\left(\mathrm{S}^{-}\right)$during the consumption of the organic carbon (Canfield and Berner, 1987; Farina et al., 1990; Mann et al., 1990).

Authigenic magnetic iron sulfides (i.e., pyrrotite $[\mathrm{FeS}]$ and greigite $\left.\left[\mathrm{Fe}_{3} \mathrm{~S}_{4}\right]\right)$ are intermediate mineral phases within the chemical iron reduction series that eventually form nonmagnetic pyrite $\left(\mathrm{FeS}_{2}\right.$; Canfield and Berner, 1987). However, the mineral greigite, in particular, has been found in both recent (e.g., Snowball, 1991) and ancient (Reynolds et al., 1994) sediments suggesting that this mineral can exist unaltered for significant periods of time.

In this paper, we present the results of the magnetic hysteresis measurements of four samples (Table 1) recovered from Leg 155 sites (Fig.1). The four samples contain authigenic magnetic iron sulfide minerals, three of which are iron sulfide nodules and the other is from a black iron sulfide crust. In addition, a nodule from deeper in the Sample (Samples 155-941B-12H-3, 100 and $101 \mathrm{~cm}$ ) was measured for X-ray diffraction. A sample from the "hardpan" layer, the boundary between the upper well-oxygenated sediments (Unit I) and the lower oxygen-depleted sediments (Unit II), was included in this study.

All the samples studied here are from the Upper and Middle Fan regions, between $\sim 3000$ and $4000 \mathrm{~m}$ water depth. Five of these samples were from the top two cores from these sites with a maximum depth of $\sim 11.5$ meters below seafloor (mbsf). The sample from Core $155-941 \mathrm{~B}-12 \mathrm{H}$ was at the base of a debris flow at about $83 \mathrm{mbsf}$.

Within the lithologic unit scheme, most of the nodules and the crust are within lithologic Subunit IIA, which consists of fine-grained particles (clay/clayey silt) probably delivered as spillover turbidites. Within the "Amachron" units scheme (Flood, Piper, Klaus, et al., 1995), Subunit IIA is within the Amazon Channel system, the most

${ }^{1}$ Flood, R.D., Piper, D.J.W., Klaus, A., and Peterson, L.C. (Eds.), 1997. Proc. ODP, Sci. Results, 155: College Station, TX (Ocean Drilling Program).

${ }^{2}$ College of Marine Studies, University of Delaware, Newark, DE 19716, U.S.A. frhall@udel.edu

${ }^{3}$ Department of Geological Sciences, University of California, Santa Barbara, CA 93103, U.S.A.

${ }^{4}$ Graduate School of Oceanography, University of Rhode Island, Narragansett, RI 02882, U.S.A.
Table 1. Magnetic hysteresis parameters of the samples used in this study.

\begin{tabular}{|c|c|c|c|c|c|c|}
\hline Sample & $\begin{array}{c}\text { Sample } \\
\text { type }\end{array}$ & $\begin{array}{r}\text { Mass } \\
(\mathrm{mg})\end{array}$ & $\begin{array}{l}\mathrm{Hc} \\
(\mathrm{Oe})\end{array}$ & $\begin{array}{l}\mathrm{Hcr} \\
(\mathrm{Oe})\end{array}$ & $\begin{array}{c}\mathrm{Mrs} \\
\mathrm{memu} / \mathrm{g}\end{array}$ & $\begin{array}{c}\mathrm{Ms} \\
\mathrm{memu} / \mathrm{g}\end{array}$ \\
\hline 931B-1H-CC, 19 and 21 (1A) & Hardpan & 5.9 & 131 & 310 & 3.06 & 15.1 \\
\hline $931 \mathrm{~B}-1 \mathrm{H}-\mathrm{CC}, 19$ and 21 (1B) & Hardpan & 3.6 & 127 & 302 & 3 & 15.5 \\
\hline $931 \mathrm{~B}-1 \mathrm{H}-\mathrm{CC}, 19$ and 21 (1) & Hardpan & 3.6 & 301 & 534 & 17.9 & 43.4 \\
\hline $931 \mathrm{~B}-1 \mathrm{H}-\mathrm{CC}, 19$ and 21 (2) & Hardpan & 5.3 & 215 & 512 & 8.61 & 30.3 \\
\hline $937 \mathrm{~A}-1 \mathrm{H}-4,33(2 \mathrm{~A})$ & Nodule & 4.5 & 186 & 324 & 33.4 & 89.8 \\
\hline $937 \mathrm{~A}-1 \mathrm{H}-4,33(2 \mathrm{~B})$ & Nodule & 4.4 & 172 & 270 & 92.9 & 221 \\
\hline $939 \mathrm{C}-2 \mathrm{H}-3,116$ and $118(3 \mathrm{~A})$ & Crust & 2.4 & 318 & 460 & 1590 & 3160 \\
\hline $939 \mathrm{C}-2 \mathrm{H}-3,116$ and 118 (3B) & Crust & 2.6 & 243 & 371 & 1050 & 2330 \\
\hline $939 \mathrm{C}-2 \mathrm{H}-3,116$ and 118 (1) & Crust & 4.2 & 304 & 437 & 1050 & 2110 \\
\hline $939 \mathrm{C}-2 \mathrm{H}-3,116$ and 118 (2) & Crust & 10 & 296 & 438 & 260 & 485 \\
\hline $944 \mathrm{~A}-1 \mathrm{H}-2,105(4 \mathrm{~A})$ & Nodule & 3.6 & 370 & 531 & 977 & 1960 \\
\hline $944 \mathrm{~A}-1 \mathrm{H}-2,105$ (4B) & Nodule & 8.3 & 381 & 539 & 913 & 1790 \\
\hline $944 \mathrm{~A}-1 \mathrm{H}-2,105(2)$ & Nodule & 8.4 & 389 & 558 & 533 & 1080 \\
\hline $944 \mathrm{D}-1 \mathrm{H}-3,112(5 \mathrm{~A})$ & Nodule & 5.3 & 440 & 577 & 7000 & 11800 \\
\hline $944 \mathrm{D}-1 \mathrm{H}-3,112$ (5B) & Nodule & 5.1 & 416 & 548 & 5570 & 9410 \\
\hline $944 \mathrm{D}-1 \mathrm{H}-3,112(1)$ & Nodule & 6.3 & 441 & 566 & 4200 & 6910 \\
\hline
\end{tabular}

recently active portion of the Amazon Fan, and is latest Pleistocene in age. The hardpan sample is a mud interpreted to represent the Holocene/Pleistocene boundary.

\section{METHODS}

During the cruise, the locations of nodules were determined by significant peaks in the whole-core magnetic susceptibility record. The samples were removed from the working halves of the cores using a nonmagnetic, stainless steel spatula and placed into $5-\mathrm{cm}^{3}$ plastic cubes. The samples were then placed in a plastic laboratory bag, and refrigerated.

Subsamples were measured for magnetic hysteresis at room temperature using the Princeton Measurements Corporation Model 2600 Micromag magnetometer at the University of Rhode Island with a maximum applied field of $1 \mathrm{~T}$. Subsamples were examined with the scanning electron microscope (SEM) with chemical compositions estimated using the EDS system. Camera X-ray diffraction was performed on Samples 155-941B-12H-3, 100 and $101 \mathrm{~cm}$. SEM and Xray diffraction were performed at the Geology Department, University of Delaware. Magnetic-mineral separation was not performed on these samples.

\section{RESULTS}

The locations of these nodules and the iron sulfide crust with respect to the whole-core magnetic susceptibility curves for these sites 


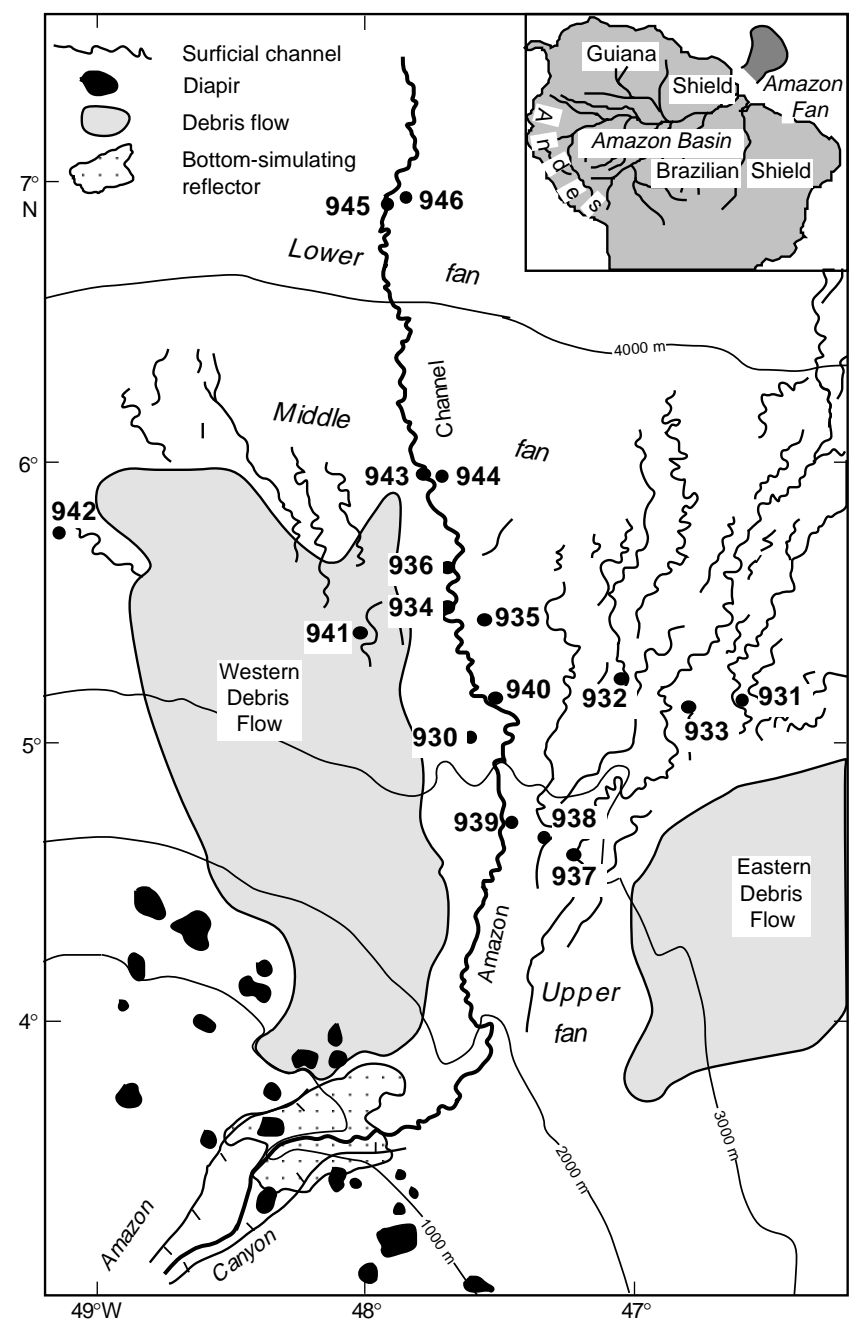

Figure 1. Location of the Amazon Fan showing all of the drilled sites. Modified from Flood et al., 1995; modified from Damuth et al., 1988 and Manley and Flood, 1988.

are given in Figure 2. The peak in susceptibility at which the sample was extracted from Hole 937C is similar to a feature in Hole 937B (see Hall, this volume). Furthermore, the peak from which a sample was taken in Hole 944A occurs at the same stratigraphic level as the sample from Hole 944D although the sample was deeper within the core of Hole 944D.

The camera X-ray diffraction patterns of Samples 941B-12H-3, 100 and $101 \mathrm{~cm}$, are given in Figure 3A. The d-spacings ( $\mathrm{A})$ of the six most prominent peaks in this pattern are given on this figure: 11 total peaks were identified. The pattern shown in Figure 3 is consistent with the mineral greigite.

With the scanning electron microscope, a single iron-rich crystal was detected within Sample 155-944D-1H-3, $112 \mathrm{~cm}$ (Fig. 3B). This crystal is small $(<2 \mu \mathrm{m})$ and euhedral in shape. The results of the EDS analyzer for Samples 155-941B-12H-3, 100 and $101 \mathrm{~cm}$, and 155944D-1H-3, $112 \mathrm{~cm}$ (Fig. 4), detected high Fe and S concentrations. However, Fe and $\mathrm{S}$ were not detectable within Samples 155-931B$1 \mathrm{H}-\mathrm{CC}, 19$ and $21 \mathrm{~cm}$ (hardpan).

Figure 5 shows the magnetic hysteresis pattern for Sample 155944D-1H-3, $112 \mathrm{~cm}$, with the hysteresis parameters Mr, Mrs, Hc, and Hcr of all samples measured given in Table 1 . The magnetic hysteresis curves for all samples are available from the ODP database. Figure 6 shows the log-log plots (6A: Roberts, 1995) and the average Hcr (coercivity) values (6B) of the samples with 1 standard-deviation error bars. The slope of the line from the data is close to 0.5 , suggesting single-domain behavior (Roberts, 1995). In addition, all iron sulfide samples show a relatively high coercivity with respect to the hardpan layer.

\section{DISCUSSION}

The result of camera X-ray diffraction shows that the authigenic magnetic iron sulfide particles are probably composed of greigite. This interpretation is consistent with the chemical compositions of Samples 155-941B-12H-3, 100 and $101 \mathrm{~cm}$, and 155-944D-1H-3, $112 \mathrm{~cm}$. These crystals are fine-grained $(<2 \mu \mathrm{m})$, and the magnetic hysteresis results are similar to those discussed by Roberts (1995) suggesting that the greigite in these samples exhibits single-domain behavior.

The observed iron sulfide nodules grow in the clay/silt matrix within the upper $11 \mathrm{~m}$ of the levee sediments. Within the Amachron system (Flood, Piper, Klaus, et al., 1995), the levee sediments studied here are of "Amazon Channel" age (latest Pleistocene: typically clay/ silty clay [lithologic Unit II/IIA]). Hall et al. (this volume) show that these sediments have high $\mathrm{IRM}_{1.2 \mathrm{~T}} / \mathrm{K}$ values (values ranged from 30 to $60 \mathrm{~mA} / \mathrm{m}$ ), which is typical of greigite (Snowball, 1991).

Although rock-magnetic evidence suggests that greigite is prevalent in these sediments, the formation of nodules is patchy at best. But, when present, these nodules are detectable using whole-core magnetic susceptibility and occur at the same stratigraphic levels in multiple holes from the same site.

The production of these iron sulfides is further enhanced by the relatively high organic carbon contents of these sediments (Flood, Piper, Klaus, et al., 1995). Furthermore, the fact that these sediments are turbidites implies rapid sedimentation and burial.

The hardpan layer is believed to have been formed immediately following a postglacial sea-level rise that cut off the development of turbidity currents from the shelf region. This layer is interpreted to represent the Holocene/Pleistocene boundary (Flood, Piper, Klaus, et al., 1995). The hardpan sediment further represents the boundary between two chemical diagenetic zones (the upper well-oxygenated sediments [lithologic Unit I] and the lower oxygen-depleted sediments [lithologic Unit II/IIA]) and was probably stripped of finegrained iron oxide minerals. The chemical composition of this layer shows that it is depleted in iron. Furthermore, the magnetic hysteresis parameters show that the magnetic mineralogy is coarse grained and lower in coercivity than the other samples.

The results of these analyses demonstrate that this region provides an excellent laboratory for examining reduction diagenesis in a deepmarine environment. However, as both geological and chemical sampling within these cores were required to be at coarse intervals, detailed examination of this process was not possible. As the locations of most of the nodules presented here are within the upper $11 \mathrm{~m}$ of sediment, returning to the Amazon Fan will allow scientists to more carefully examine the chemical processes affecting this area.

\section{CONCLUSIONS}

The results of these analyses show that:

1. Magnetic iron sulfide minerals sampled during Leg 155 consist of fine-grained, single-domain greigite.

2. Iron sulfide minerals were not detected on the hardpan Sample 155-931B-1H-CC, 19 and $21 \mathrm{~cm}$. In addition, these minerals were also absent in the topmost Holocene sediment.

3. The locations of these nodules within a sedimentary sequence is patchy-not observed at the same depths in holes from the same site, but observed at contemporaneous horizons at the same site. 

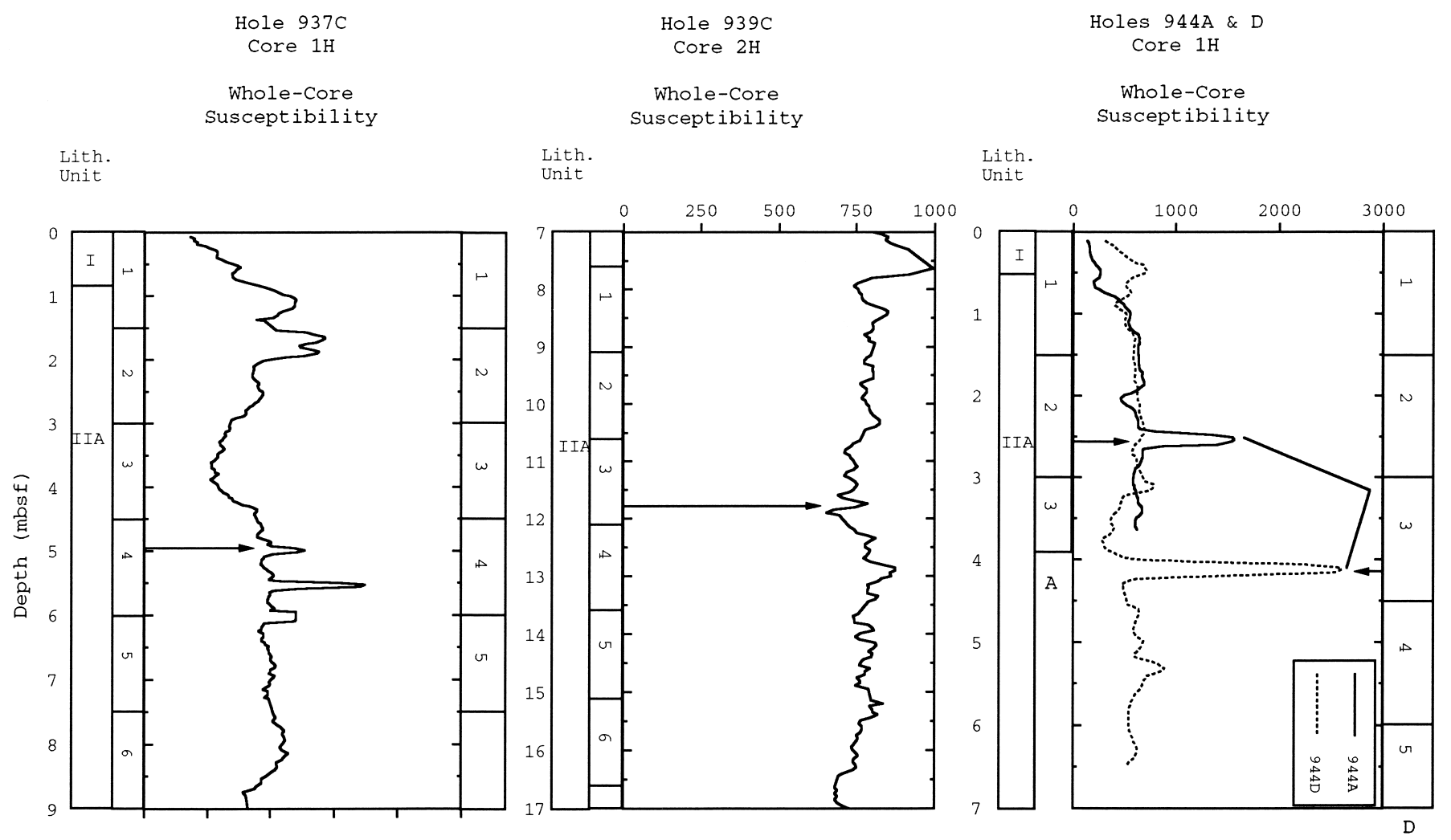

Figure 2. The whole-core magnetic susceptibility curves for the cores from which these samples were extracted. Section numbers of the cores are given on the margins of the plot. These data were smoothed using a 5-point running mean before plotting. The data are given in units of $10^{-5} \mathrm{SI}$.

\section{ACKNOWLEDGMENTS}

We particularly thank Dr. Eve Arnold for the X-ray diffraction measurements of these samples and Dr. John Peck for assistance with the hysteresis analyses. We further thank Dr. Billy P. Glass and Ms. Takako Nagase for assistance in the SEM analyses. In particular, we thank Drs. Richard Reynolds and Andrew Roberts for comments made when reviewing this article. This project was supported by USSAC No. 155-20846b.

\section{REFERENCES}

Canfield, D.E., and Berner, R.A., 1987. Dissolution and pyritization of magnetite in anoxic marine sediments. Geochim. Cosmochim. Acta, 51:645659.

Damuth, J.E., Flood, R.D., Knowsmann, R.O., Belderson, R.H., Gorini, M.A., 1988. Anatomy and growth patterns of Amazon deep-sea fan as revealed by long-range side-scan sonar (GLORIA) and high-resolution seismic studies. AAPG Bull., 72:885:911.

Farina, M., Eaquivel, D.M., and Lins de Barros, H.G.P., 1990. Magnetic ironsulphur crystals from a magnetotactic microorganism. Nature, 323:256258.

Flood, R.D., Piper, D.J.W., and Shipboard Scientific Party, 1995. Introduction. In Flood, R.D., Piper, D.J.W., Klaus, A., et al., Proc. ODP, Init. Repts., 155: College Station, TX (Ocean Drilling Program), 5-16.
Flood, R.D., Piper, D.J.W., Klaus, A., et al., 1995. Proc. ODP, Init. Repts., 155: College Station, TX (Ocean Drilling Program).

Karlin, R., and Levi, S., 1983. Diagenesis of magnetic minerals in recent hemipelagic sediments. Nature, 303:327-330.

Manley, P.L., and Flood, R.D., 1988. Cyclic sediment deposition within the Amazon deep-sea fan. AAPG Bull., 72:912-925.

Mann, S., Sparks, N.H.C., Frankel, R.B., Bazylinski, D.A., and Jannasch, H.W., 1990. Biomineralization of ferrimagnetic greigite $\left(\mathrm{Fe}_{3} \mathrm{~S}_{4}\right)$ and iron pyrite $\left(\mathrm{FeS}_{2}\right)$ in a magnetotactic bacterium. Nature, 343:258-261.

Reynolds, R.L., Tuttle, M.L., Rice, C.A., Fishman, N.S., Karachewski, J.A., and Sherman, D.M., 1994. Magnetization and geochemistry of greigitebearing Cretaceous strata, North Slope Basin, Alaska. Am. J. Sci., 294:485-528.

Roberts, A.P., 1995. Magnetic properties of sedimentary greigite $\left(\mathrm{Fe}_{3} \mathrm{~S}_{4}\right)$. Earth Planet. Sci. Lett., 134:227-236.

Snowball, I.F., 1991. Magnetic hysteresis properties of greigite $\left(\mathrm{Fe}_{3} \mathrm{~S}_{4}\right)$ and a new occurrence in Holocene sediments from Swedish Lappland. Phys. Earth Planet. Inter., 68:32-40.

Date of initial receipt: 12 December 1995

Date of acceptance: 29 July 1996

Ms 155SR-216 


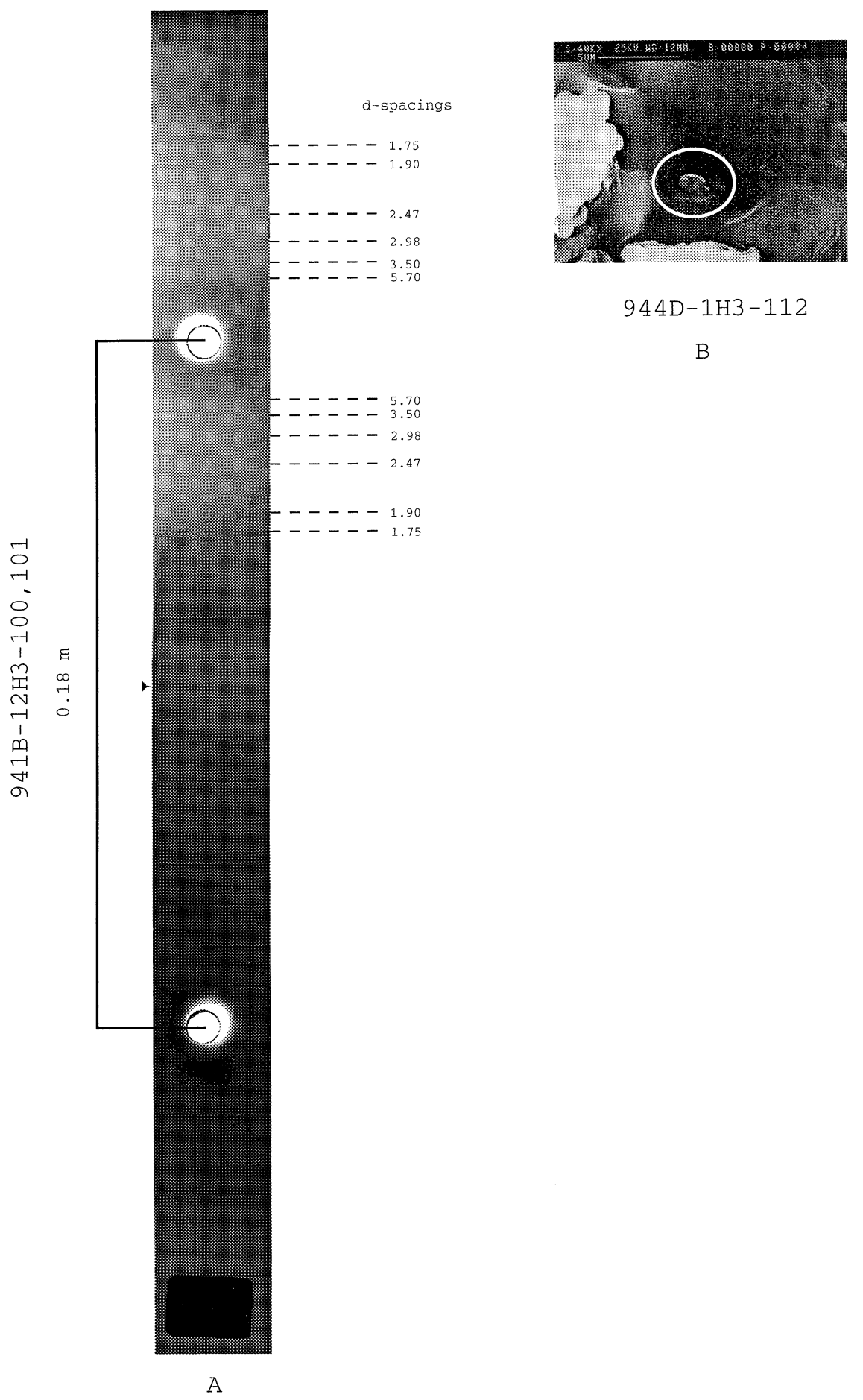

Figure 3. (A) X-ray diffractogram and (B) scanning-electron photo of Samples 155-941B-12H-3, 100 and $101 \mathrm{~cm}$; and 155-944D-1H-3, 112 cm. The circled portion of (B) is an iron sulfide crystal. 
A

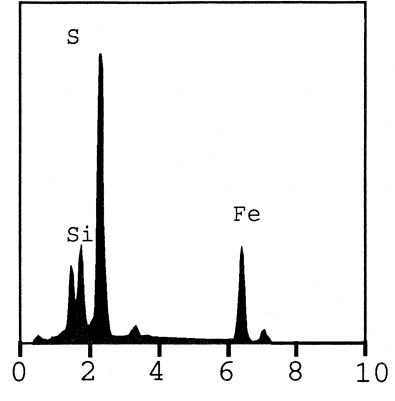

C

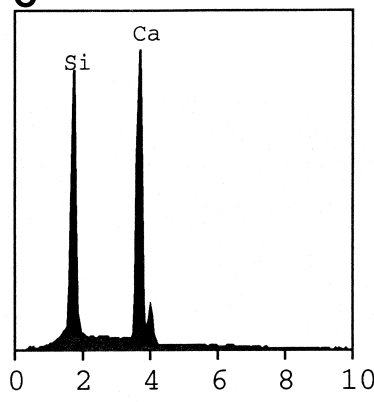

Energy Channel (keV)

Figure 4. The results of EDS chemical analyses of sediment Samples (A) 155-941B-12H-3, 100 and $101 \mathrm{~cm}$; (B) 155-944D-1H3, $112 \mathrm{~cm}$; and (C) 155931B-1H-CC, 19 and $21 \mathrm{~cm}$ (hardpan sample).

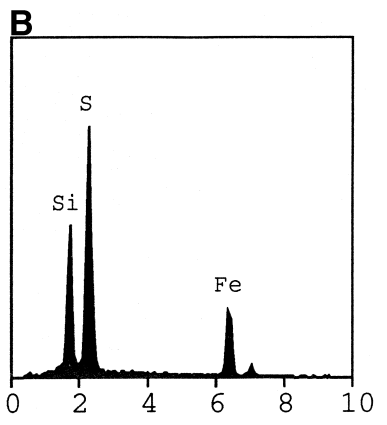

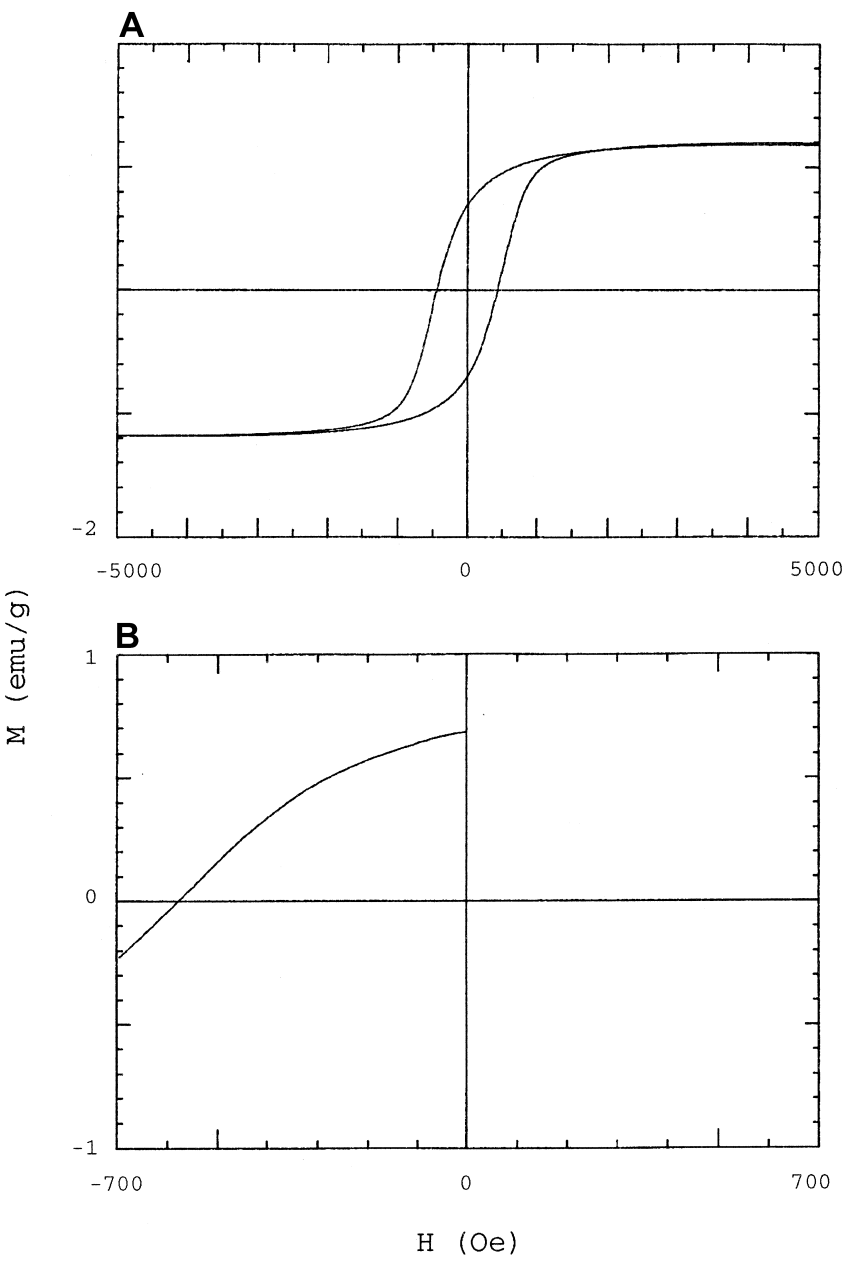

Figure 5. The (A) magnetic hysteresis and (B) coercivity curve for Sample 155-944D-1H3, $112 \mathrm{~cm}$.

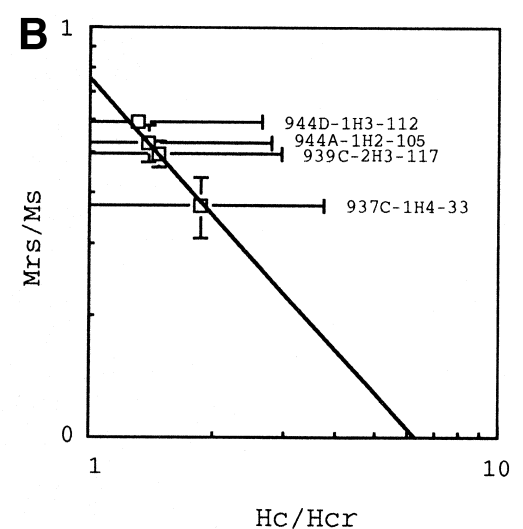

Figure 6. $\log -\log$ plots of Mrs/Ms vs. Hc/Hcr for the iron sulfide samples. A. All data points. B. Average values for individual samples with 1 standard deviation error bars. The line drawn on the figure has a slope of 0.5 (Roberts, 1995). 